\title{
CLINICAL STUDIES OF THE BLOOD VOLUME. II. THE RELATION \\ OF PLASMA AND TOTAL BLOOD VOLUME TO VENOUS PRES- \\ SURE, BLOOD VELOCITY RATE, PHYSICAL MEASURE- MENTS, AGE AND SEX IN NINETY NORMAL HUMANS
}

\author{
By JOHN G. GIBSON, 2ND ANd WILLIAM A. EVANS, JR. \\ (From the Medical Clinic of the Peter Bent Brigham Hospital and the Department of Medicine, \\ Harvard Medical School, Boston)
}

(Received for publication January 27, 1937)

Medical literature contains several works on the blood volume in normal persons, based on findings with the dye method of Keith, Rowntree and Geraghty (1) or modifications thereof, $(2,3,4)$. Our justification for presenting an additional study is that the principal errors inherent in the earlier techniques are minimized by the dye method we have employed. By this method, described in detail in a previous communication (5), the absolute plasma volume can be measured with considerable accuracy, and the calculation of total blood volume is based on the plasma volume and the hematocrit values of venous blood samples. It also seemed worth while to consider the normal blood volume in relation to physical measurements of the individuals and to certain aspects of hemodynamics, to determine what interrelations exist.

This study comprises an analysis of the plasma and total blood volumes, venous pressures and blood velocity rates determined in 90 adult individuals, 49 of whom were males and 41 females. These subjects were hospital patients with no evidence by history or on physical examination of cardiovascular or renal disease, blood dyscrasias or debilitating disorders, and members of the hospital staff in good health.

Plasma and total blood volumes, venous pressures and blood velocity rates were determined with the subjects in a basal state. Results are summarized in Table $\mathrm{I}$.

\section{Sex}

The plasma and total blood volumes of all our subjects, considered by age and sex, are shown in Figure 1, and the corresponding plasma and total blood volume in cc. per $\mathrm{kgm}$. of body weight in Figure 2. At once apparent is the striking difference in volumes of males and females, the average absolute and per $\mathrm{kgm}$. plasma volume of females being 22.5 per cent and 3.7 per cent less, and absolute and per $\mathrm{kgm}$. total blood volume 28.8 per cent and 4.7 per cent less than that of males, respectively.

An extreme range of about 30 per cent above and below average plasma and total blood volumes is encountered in individuals, as shown in Figure 3 , but no particular difference in range obtains between sexes. In about two-thirds of the cases in this series, plasma and total blood volumes were within 10 per cent above or below average values; of the remaining one-third, an approximately equal number were above and below that limit.

$$
\text { Age }
$$

Analysis of absolute and relative volumes by decades (see Figures 1 and 2), shows a tendency in both sexes for values to remain at or rise somewhat above the average levels of the series during middle life and to decline with advancing age. The increase in total volume in terms of body weight during middle age is more pronounced in males than in females, while the decrease after the fourth decade, apparent in both sexes, is greater in females than in males, being about 16 per cent below middle age values in women and 8 per cent in men.

\section{Height, weight, and surface area}

There is an increase in total blood volume with increasing individual height, weight and surface area as calculated from the nomogram of Boothby and Sandiford given by DuBois (6), the relationships being as shown in Figure 4. In relation to all three of these physical measurements, in about 70 per cent of our cases total volume is within 10 
per cent above or below the average value for the group in both sexes. As regards weight only, those cases having volumes above these limits were predominantly muscular individuals, those falling below were for the most part tall and thin.
The relation of total volume in cc. per $\mathrm{kgm}$. to variations in body weight is shown in Figure 5B, in which it will be noted that in both sexes, unit volume tends to rise with increase in weight of individuals, reaches a maximum at a lower weight level in females than in males, and thereafter

TABLE I

The absolute and relative plasma and total blood volume, physical measurements, venous pressure, blood velocty rate andi hematocrit in adult normal men and women

\begin{tabular}{c|c|c|c|c|c|c|c|c|c|c|c|c|}
\hline \hline $\begin{array}{c}\text { Case } \\
\text { ber }\end{array}$ & Date & Age & Height & Weight & $\begin{array}{c}\text { Surface } \\
\text { area }\end{array}$ & $\begin{array}{c}\text { Venous } \\
\text { pressure }\end{array}$ & $\begin{array}{c}\text { Blood } \\
\text { velocity } \\
\text { rate }\end{array}$ & $\begin{array}{c}\text { Hemato- } \\
\text { crit }\end{array}$ & Plasma volume & Total blood volume \\
\hline & & years & $c m$. & kgm. & square meters & mm. $\mathrm{H}_{2} \mathrm{O}$ & seconds & & $c c$. & cc. per kgm. & $c c$. & cc. per kgm. \\
\hline
\end{tabular}

MALES-49

\begin{tabular}{|c|c|c|c|c|c|c|c|c|c|c|c|c|}
\hline $\begin{array}{l}3 \\
6 \mathrm{~A} \\
17 \\
20 \mathrm{~B} \\
32 \mathrm{~A} \\
34 \\
46 \mathrm{~A} \\
58 \\
66 \\
69 \\
73 \\
74 \\
82 \mathrm{~B} \\
86 \mathrm{~A} \\
127 \\
130 \\
131 \\
138 \\
140 \mathrm{~B} \\
142 \\
148 \\
155 \\
161 \\
177 \\
180 \\
193 \\
196 \\
197 \\
198 \\
199 \mathrm{~B} \\
200 \\
201 \\
202 \\
203 \\
209 \\
210 \\
212 \\
215 \mathrm{~A} \\
219 \\
223 \\
224 \\
225 \\
226 \\
227 \\
229 \\
231 \mathrm{~A} \\
255 \\
257 \\
275\end{array}$ & $\begin{array}{lr}\text { November } & 23,1934 \\
\text { December } & 1,1934 \\
\text { April } & 4,1935 \\
\text { November } 29,1935 \\
\text { May } & 26,1935 \\
\text { June } & 7,1935 \\
\text { June } & 23,1935 \\
\text { July } & 4,1935 \\
\text { July } & 16,1935 \\
\text { July } & 19,1935 \\
\text { July } & 22,1935 \\
\text { July } & 23,1935 \\
\text { June } & 19,1936 \\
\text { October } & 2,1935 \\
\text { December } & 12,1935 \\
\text { December } & 17,1935 \\
\text { December } & 18,1935 \\
\text { January } & 14,1936 \\
\text { January } & 15,1936 \\
\text { January } & 18,1936 \\
\text { January } & 31,1936 \\
\text { March } & 17,1936 \\
\text { March } & 24,1936 \\
\text { May } & 6,1936 \\
\text { May } & 13,1936 \\
\text { June } & 4,1936 \\
\text { January } & 8,1936 \\
\text { February } & 26,1936 \\
\text { March } & 11,1936 \\
\text { May } & 27,1936 \\
\text { April } & 1,1936 \\
\text { April } & 22,1936 \\
\text { May } & 27,1936 \\
\text { May } & 27,1936 \\
\text { June } & 20,1936 \\
\text { June } & 22,1936 \\
\text { June } & 23,1936 \\
\text { June } & 27,1936 \\
\text { July } & 8,1936 \\
\text { July } & 16,1936 \\
\text { July } & 21,1936 \\
\text { July } & 22,1936 \\
\text { July } & 23,1936 \\
\text { July } & 27,1936 \\
\text { July } & 29,1936 \\
\text { August } & 6,1936 \\
\text { December } & 3,1936 \\
\text { December } & 8,1936 \\
\text { January } & 11,1937\end{array}$ & $\begin{array}{l}26 \\
23 \\
22 \\
26 \\
37 \\
21 \\
28 \\
62 \\
41 \\
19 \\
26 \\
24 \\
30 \\
23 \\
26 \\
58 \\
89 \\
27 \\
22 \\
43 \\
39 \\
22 \\
27 \\
60 \\
19 \\
58 \\
28 \\
38 \\
43 \\
31 \\
44 \\
37 \\
44 \\
45 \\
24 \\
24 \\
27 \\
25 \\
57 \\
41 \\
30 \\
51 \\
38 \\
39 \\
44 \\
42 \\
39 \\
30 \\
20\end{array}$ & $\begin{array}{l}182.9 \\
175.2 \\
173.0 \\
176.0 \\
174.5 \\
153.4 \\
170.0 \\
161.3 \\
180.2 \\
157.4 \\
173.6 \\
160.0 \\
171.3 \\
168.6 \\
180.1 \\
185.4 \\
178.7 \\
185.3 \\
180.1 \\
173.2 \\
185.3 \\
167.6 \\
170.0 \\
172.6 \\
172.1 \\
167.3 \\
166.4 \\
188.3 \\
161.5\end{array}$ & $\begin{array}{l}70.4 \\
71.4 \\
77.3 \\
74.6 \\
70.4 \\
68.2 \\
71.8 \\
65.2 \\
63.2 \\
65.0 \\
66.0 \\
76.2 \\
63.3 \\
59.6 \\
84.2 \\
78.2 \\
55.2 \\
78.0 \\
76.1 \\
71.0 \\
54.3 \\
79.4 \\
72.4 \\
68.0 \\
48.6 \\
64.6 \\
73.3 \\
63.3 \\
62.8 \\
63.0 \\
43.7 \\
59.8 \\
68.7 \\
89.0 \\
78.2 \\
73.0 \\
83.0 \\
69.5 \\
62.5 \\
75.0 \\
59.0 \\
65.5 \\
73.7 \\
76.6 \\
78.1 \\
66.0 \\
55.0 \\
93.6 \\
53.2\end{array}$ & $\begin{array}{l}1.99 \\
1.91 \\
1.83 \\
1.94 \\
1.85 \\
1.43 \\
1.74 \\
1.77 \\
1.79 \\
1.63 \\
1.75 \\
1.41 \\
1.69 \\
1.78 \\
2.24 \\
2.01 \\
1.90 \\
2.06 \\
1.87 \\
1.73 \\
1.97 \\
1.66 \\
1.73\end{array}$ & $\begin{array}{r}115 \\
60 \\
70 \\
90 \\
90 \\
65 \\
40 \\
70 \\
115 \\
115 \\
80 \\
80 \\
70 \\
130 \\
75 \\
100 \\
80 \\
120 \\
110 \\
45 \\
120 \\
95 \\
120 \\
30 \\
100 \\
85 \\
85 \\
110 \\
65 \\
75 \\
60 \\
110 \\
70 \\
65 \\
80 \\
85 \\
65\end{array}$ & $\begin{array}{l}18 \\
19 \frac{1}{2} \\
17 \\
19 \\
18 \frac{1}{2} \\
14 \\
18 \\
17 \\
17 \\
14 \frac{1}{2} \\
14 \\
16 \\
19 \\
22 \\
20 \\
17 \\
\\
16 \\
15 \\
17 \\
14 \\
18 \\
17\end{array}$ & $\begin{array}{l}44.6 \\
42.1 \\
42.4 \\
44.4 \\
45.0 \\
45.3 \\
46.7 \\
44.4 \\
44.5 \\
45.4 \\
48.7 \\
47.8 \\
43.0 \\
44.1 \\
43.2 \\
51.8 \\
36.0 \\
44.3 \\
44.7 \\
48.8 \\
45.2 \\
49.4 \\
48.3 \\
49.3 \\
48.4 \\
43.3 \\
48.6 \\
40.2 \\
42.2 \\
42.0 \\
40.9 \\
46.0 \\
42.4 \\
39.8 \\
42.5 \\
41.8 \\
44.5 \\
41.4 \\
38.1 \\
48.8 \\
48.0 \\
42.6 \\
43.6 \\
46.0 \\
46.9 \\
45.8 \\
42.3 \\
47.5 \\
46.2\end{array}$ & $\begin{array}{l}2620 \\
4045 \\
3890 \\
2830 \\
2945 \\
3090 \\
2985 \\
3140 \\
2760 \\
2420 \\
2980 \\
2700 \\
2530 \\
2340 \\
3200 \\
2400 \\
3210 \\
3190 \\
3040 \\
2690 \\
2380 \\
3080 \\
2840 \\
2550 \\
1855 \\
2940 \\
2760 \\
3500 \\
2280 \\
3230 \\
2135 \\
2860 \\
3020 \\
3550 \\
4000 \\
3560 \\
3660 \\
3170 \\
3040 \\
2790 \\
2765 \\
2485 \\
3670 \\
2915 \\
3260 \\
2845 \\
2530 \\
3620 \\
2180\end{array}$ & $\begin{array}{l}35.2 \\
56.8 \\
50.3 \\
37.9 \\
41.8 \\
45.3 \\
41.6 \\
47.0 \\
43.7 \\
37.2 \\
45.2 \\
35.4 \\
39.5 \\
39.2 \\
38.2 \\
32.0 \\
58.2 \\
40.9 \\
39.9 \\
38.0 \\
44.0 \\
38.8 \\
39.2 \\
37.6 \\
38.2 \\
45.5 \\
37.7 \\
55.2 \\
36.3 \\
51.3 \\
48.8 \\
47.8 \\
44.0 \\
39.9 \\
51.3 \\
48.7 \\
44.1 \\
45.6 \\
48.7 \\
39.6 \\
46.9 \\
38.0 \\
51.3 \\
38.1 \\
41.7 \\
43.2 \\
46.3 \\
38.7 \\
41.0\end{array}$ & $\begin{array}{l}4720 \\
6980 \\
6760 \\
5090 \\
5350 \\
\mathbf{5 6 5 0} \\
\mathbf{5 6 0 0} \\
\mathbf{5 6 4 0} \\
4970 \\
4360 \\
\mathbf{5 8 0 0} \\
\mathbf{5 1 6 0} \\
4480 \\
4180 \\
\mathbf{5 6 5 0} \\
\mathbf{5 1 8 0} \\
\mathbf{5 0 1 0} \\
\mathbf{5 7 3 0} \\
\mathbf{5 5 0 0} \\
\mathbf{5 2 6 0} \\
\mathbf{4 3 5 0} \\
\mathbf{6 0 8 0} \\
\mathbf{5 4 9 0} \\
\mathbf{5 0 3 0} \\
\mathbf{3 5 9 0} \\
\mathbf{5 1 9 0} \\
\mathbf{5 3 8 0} \\
\mathbf{5 8 5 0} \\
\mathbf{3 9 5 0} \\
\mathbf{5 5 7 0} \\
\mathbf{3} 610 \\
\mathbf{5 3 0 0} \\
\mathbf{5 2 5 0} \\
\mathbf{5 9 1 0} \\
\mathbf{6 9 7 0} \\
6110 \\
6600 \\
\mathbf{5 4 1 0} \\
4920 \\
5450 \\
\mathbf{5 3 2 5} \\
\mathbf{4 3 3 0} \\
\mathbf{6 5 1 0} \\
\mathbf{5 4 0 0} \\
\mathbf{6 1 4 0} \\
\mathbf{5 2 5 0} \\
\mathbf{4 4 2 0} \\
\mathbf{6 8 9 0} \\
\mathbf{4 0 5 0}\end{array}$ & $\begin{array}{l}67.1 \\
97.7 \\
87.3 \\
68.3 \\
76.0 \\
82.7 \\
78.1 \\
86.5 \\
78.6 \\
67.0 \\
88.0 \\
75.3 \\
70.2 \\
70.2 \\
67.2 \\
66.3 \\
90.8 \\
73.7 \\
72.2 \\
74.0 \\
80.1 \\
76.7 \\
75.8 \\
74.0 \\
73.8 \\
80.4 \\
73.5 \\
92.4 \\
62.7 \\
88.5 \\
82.6 \\
88.6 \\
76.3 \\
66.3 \\
89.2 \\
83.7 \\
79.5 \\
77.7 \\
78.7 \\
72.7 \\
90.3 \\
66.2 \\
90.8 \\
70.6 \\
68.7 \\
79.6 \\
80.3 \\
73.6 \\
76.2\end{array}$ \\
\hline \multicolumn{2}{|c|}{ Average } & 35.5 & 173.8 & 78.6 & 1.821 & 81.4 & 17.34 & 44.67 & 2948 & 43.08 & 5335 & 77.7 \\
\hline
\end{tabular}


TABLE I-Continued

\begin{tabular}{|c|c|c|c|c|c|c|c|c|c|c|c|c|}
\hline \multirow[t]{2}{*}{$\begin{array}{c}\text { Case } \\
\text { num- } \\
\text { ber }\end{array}$} & \multirow[t]{2}{*}{ Date } & \multirow{2}{*}{$\begin{array}{l}\text { Age } \\
\text { years }\end{array}$} & \multirow{2}{*}{$\begin{array}{c}\text { Height } \\
\mathrm{cm.}\end{array}$} & \multirow{2}{*}{ Weight } & \multirow{2}{*}{$\begin{array}{c}\begin{array}{c}\text { Surface } \\
\text { area }\end{array} \\
\text { square meters }\end{array}$} & \multirow{2}{*}{$\begin{array}{c}\begin{array}{c}\text { Venous } \\
\text { pressure }\end{array} \\
m m . \mathrm{H}_{2} \mathrm{O}\end{array}$} & \multirow{2}{*}{$\begin{array}{c}\begin{array}{c}\text { Blood } \\
\text { velocity } \\
\text { rate }\end{array} \\
\text { seconds }\end{array}$} & \multirow{2}{*}{$\begin{array}{c}\text { Hemato- } \\
\text { crit }\end{array}$} & \multicolumn{2}{|c|}{ Plasma volume } & \multicolumn{2}{|c|}{ Total blood volume } \\
\hline & & & & & & & & & $c c$. & cc. per kgm. & cc. & cc. per kgm. \\
\hline
\end{tabular}

FEMALES-41

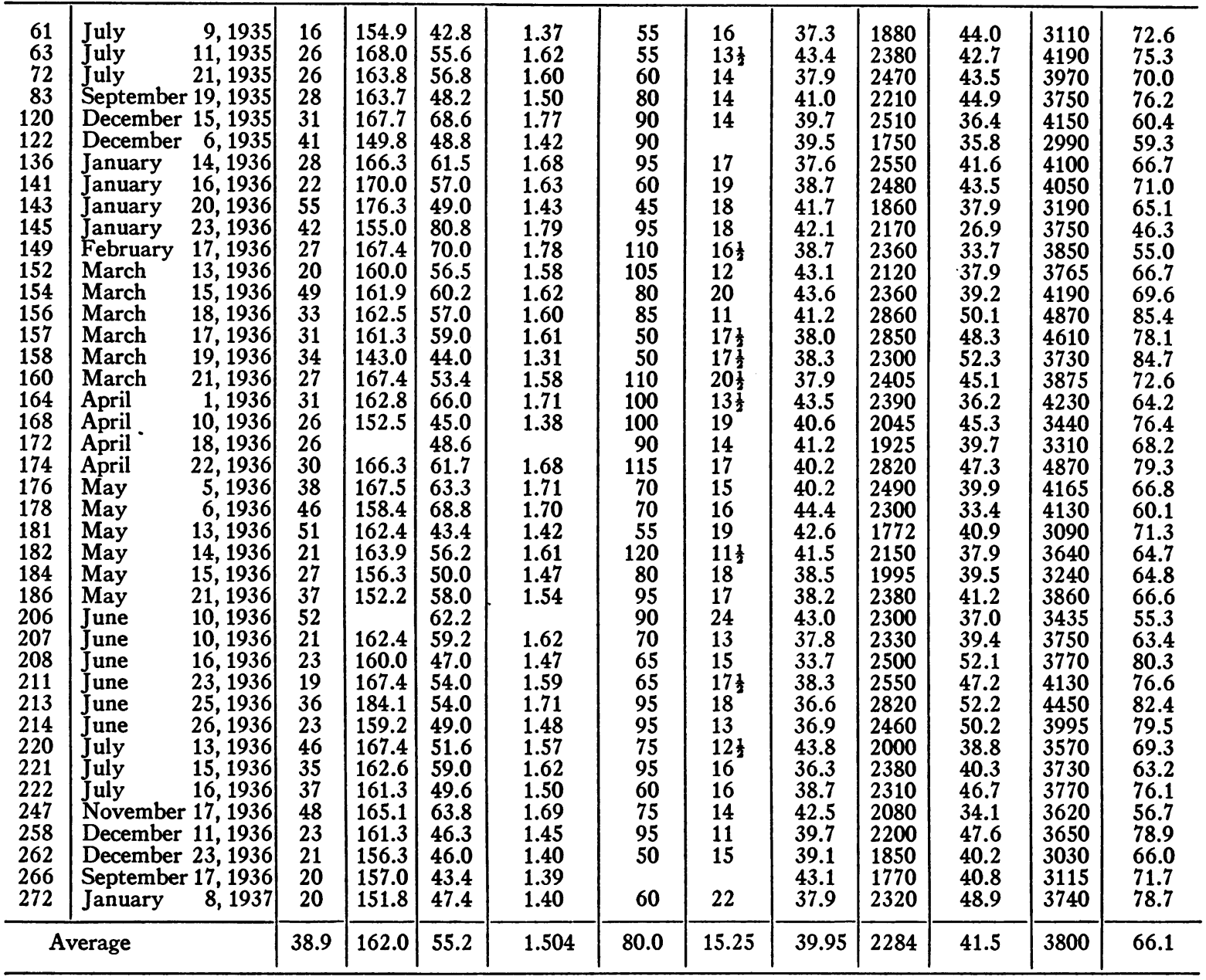

declines with further increase in weight, the decrease being more pronounced in women than in men. In relation to variations in height (Figure 5A) unit volume rises with increasing individual height, reaches a maximum value and remains quite constant with increases in height thereafter in both sexes. The composite relation of total volume to variations in both height and weight, namely, surface area (Figure 5C), clearly indicates the chief differences between the sexes in the relationship of volume to physical measurements; total blood volume in terms of surface area is about the same in small men and women, but is considerably greater in large men than in large women. In addition, with increasing individual size, unit volume in males increases steadily at a gradually lessening rate, while in females it rises to a maximum well below the level of the male maximum value and declines rather sharply thereafter.

\section{Venous pressure and blood velocity rate}

We have observed no significant variations in either venous pressure or blood velocity rate with 


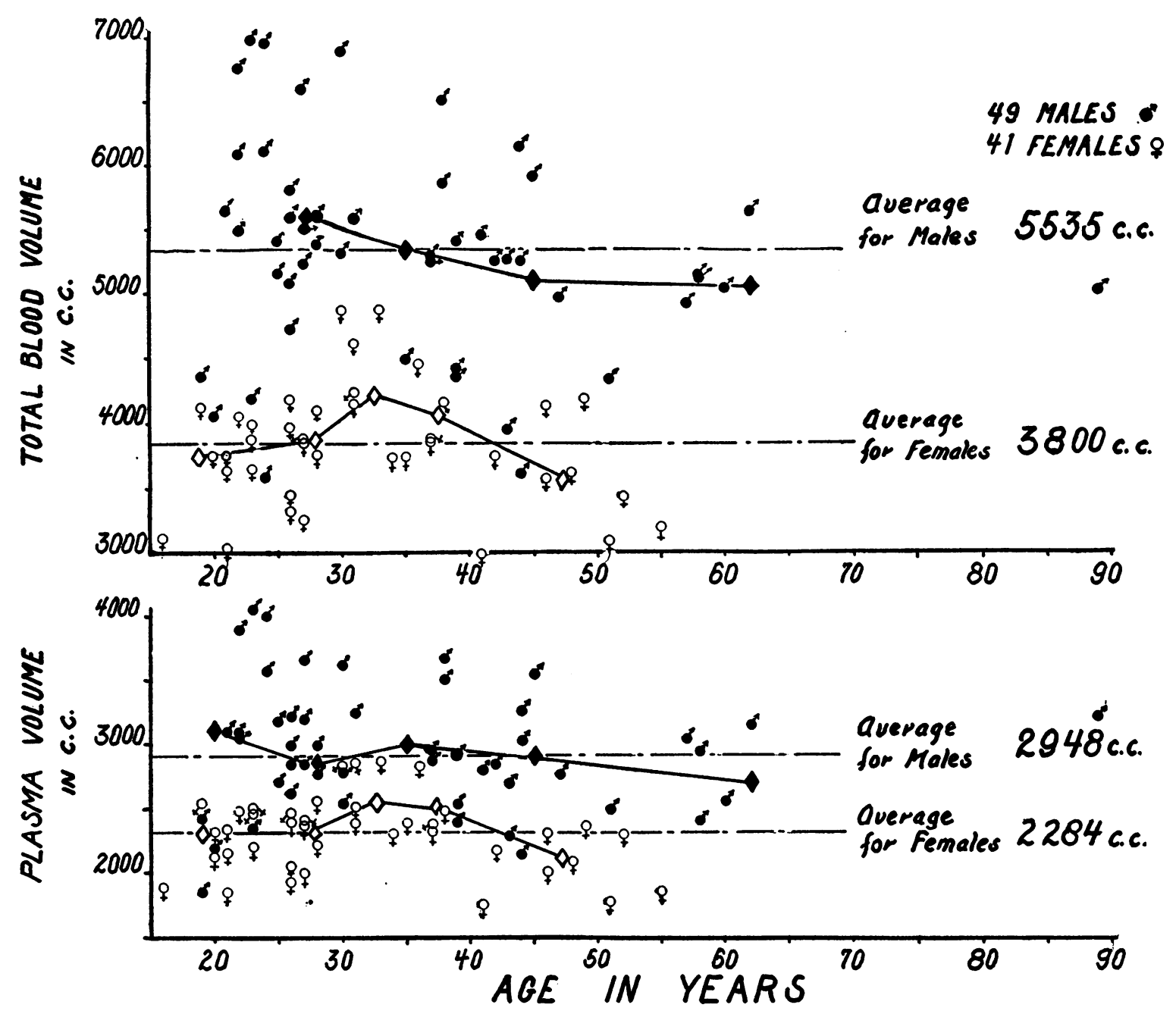

Fig. 1. Plasma and Total Blood Volume in 90 Normal Men and Women with Reference to Age

Both plasma and total blood volume of males is greater than that of females, and tend to diminish with advancing age in both sexes.

age in either sex (Figure 6). The degree of variation in individuals above and below average values for the whole group is less in the case of the blood velocity rate than in venous pressure in both sexes, but in both instances the extremes encountered in males and females are about the same. The average value of both determinations is appreciably lower in females than in males. The relation of total blood volume to variations in venous pressure and blood velocity rate is as shown in Figure 7. It is apparent that no interrelation between variations in these two measurements and blood volume exists in normal persons.

\section{Red cell volume}

In the method employed the red cell volume is based upon the hematocrit values of venous blood samples, being considered as the difference between total blood and plasma volumes. In this series the male hematocrit value ranged from 36.0 to 51.8 with an average value of 44.6 ; the female hematocrit from 33.7 to 43.8 with an average value of 39.9. Thus the average hematocrit value for females is $\mathbf{1 0 . 5}$ per cent less than that of males.

The computed average red cell volume of males is 2387 cc. and that of females 1514 cc., or 36.5 per cent less than that of males. 


\section{CRITIQUE}

Our findings are at variance with those in the literature. Thus Keith, Rowntree and Geraghty (1), Rowntree and Brown (7), Kaltreider, Hurtado and Brooks (8) and Silbert et al. (9) reported higher average absolute and relative total blood volumes for males than the average values of this series, and Bock (10) and Seyderhelm
Some of the wide divergence in values found by the above authors may be due to the limited number of cases studied, since the extreme range encountered in this series, comprising more cases than were included in any of those series referred to above, is plus or minus 30 per cent from average values. Pitfalls of the earlier methods described by Gregersen, Gibson and Stead (16)
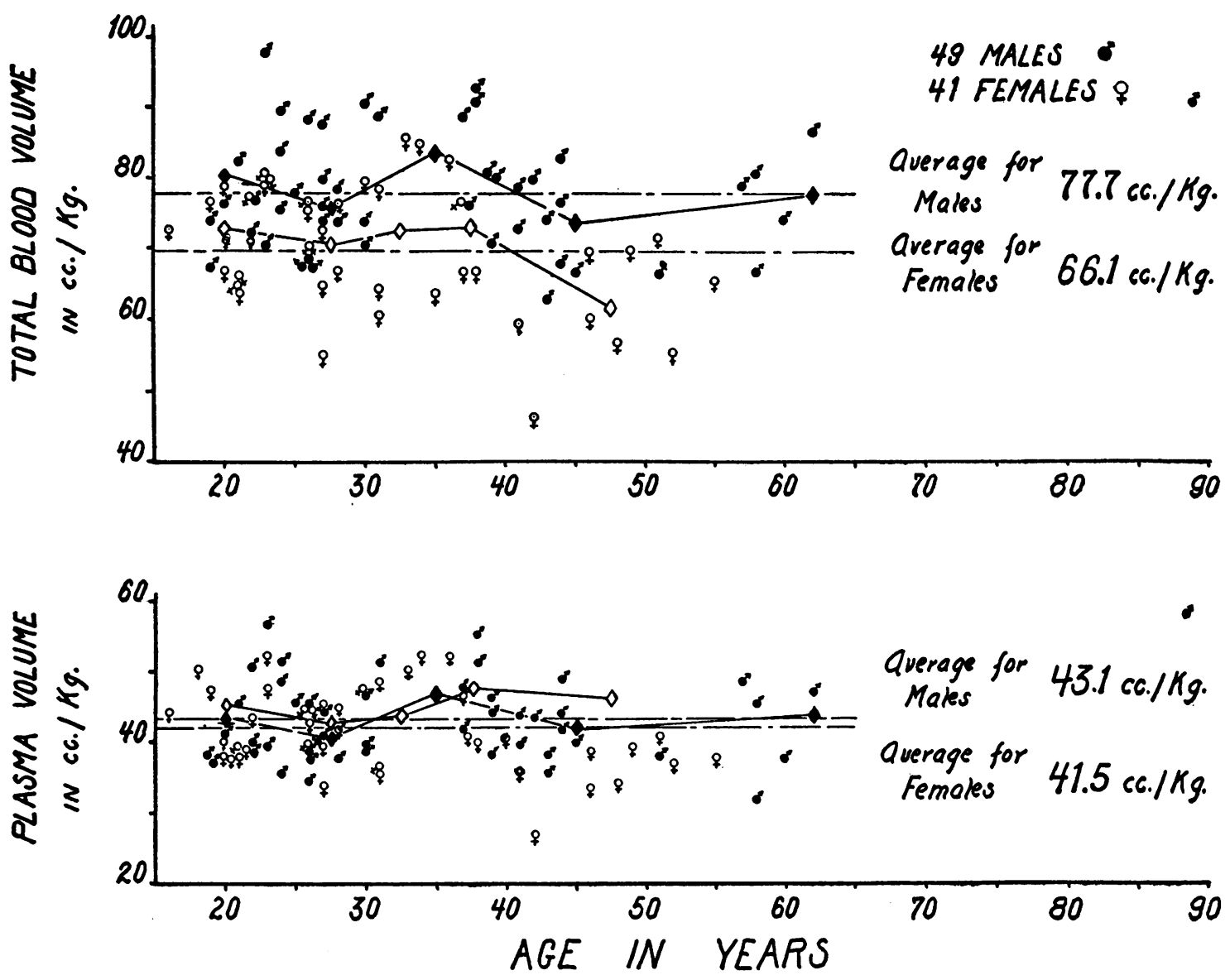

Fig. 2. Plasma and Total Blood Volume in Terms of Body Weight

The difference in total volume of males and females is due principally to the larger red cell volume of the male, the unit plasma volume of both sexes being nearly equal.

and Lampe (11) obtained higher relative total blood volumes. Wollheim (12) obtained a higher relative and lower absolute average total volume than our values. Kaboth (13) and Sparks and Haden (14) published values for women lower than those herein reported both as to absolute and relative total volume, while those of Uhlenbruck and Leyendecker (15) and Rowntree and Brown (6) were considerably higher. and in a previous communication by us (5), account in large measure for this divergence. Thus, if the volume calculation is based on the dye concentration of a single blood sample taken before the dye is completely mixed in the blood stream, falsely low values will be obtained. Inequality of dye concentration between standard and unknown may produce large errors in either direction when the Dubosq colorimeter is used, as may 
also errors due to hemolysis of dye free or dyed samples or both. While some of these errors may be compensating, it seems evident that values for normal blood volume as determined by the methods employed by the above authors cannot be regarded as reliable. tissue as muscle and viscera and blood poor tissue as bone and fat. It is accordingly consistent that muscular persons should have relatively more and fat persons relatively less blood per unit of body weight than persons of more normal habitus and proportion of brawn and blubber. Thus Cases
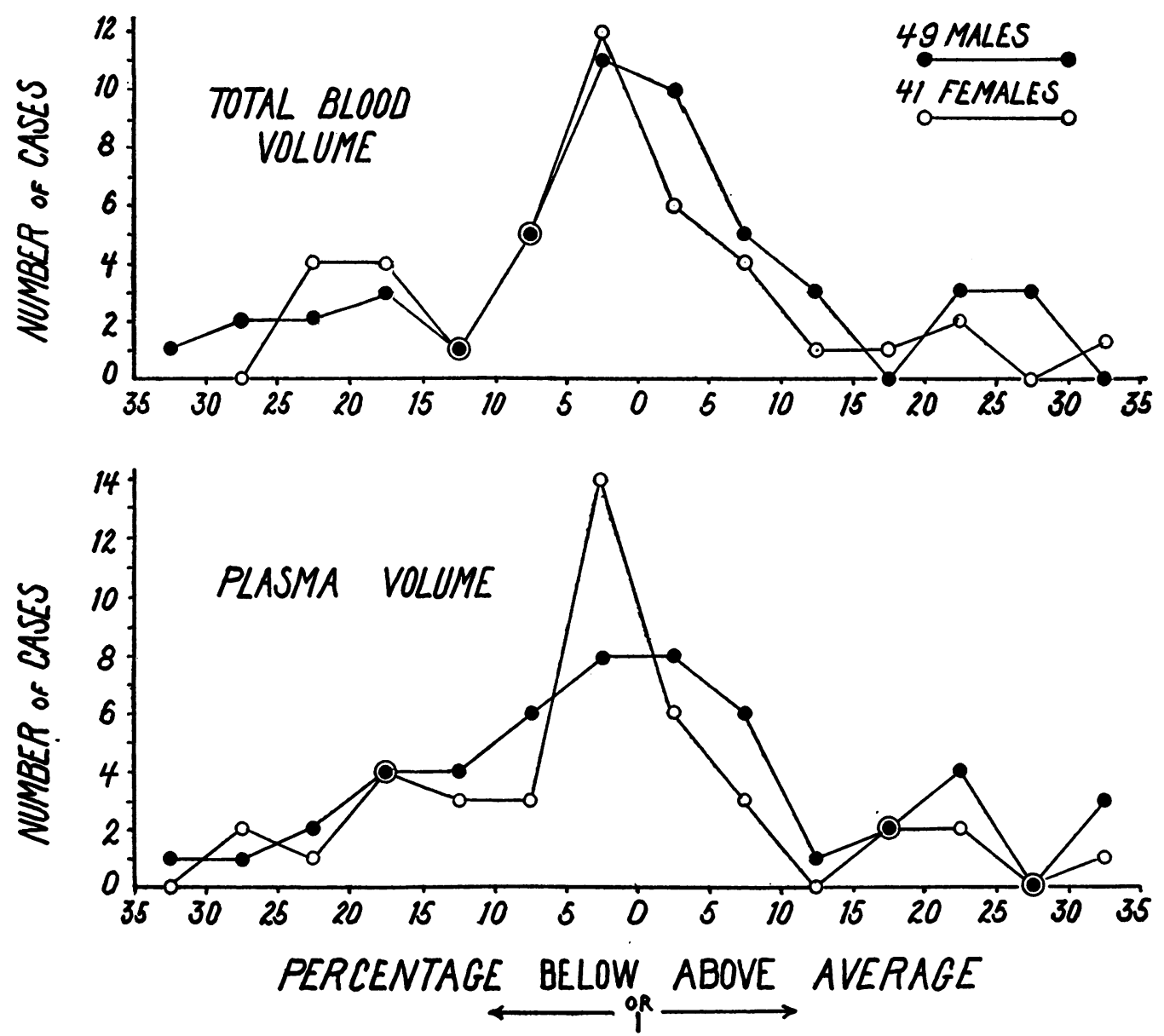

Fig. 3. Distribution of Number of Cases Above and Below Average Values for Plasma and Total Blood Volume sexes.

Our analysis of the blood volumes of normal individuals, as determined by the method we have employed indicates that differences in plasma and total blood volume of individuals of comparable age, sex, height and weight may be considerable. That extreme variations in the amount of blood in the bodies of different persons exist is not incompatible with known individual differences in build, and varying proportions of such blood rich
$6 \mathrm{~A}, 156,174,209$ and 224 are muscular persons leading physically active lives, and in all of these, both absolute and total volume per $\mathrm{kgm}$. of body weight exceeds average values. Cases 140B, 145, 149, and 203, all obese persons, have absolute volumes equal to or above the average values, but less than the average value per unit of body weight. Cases 158, 208, and 226, all underweight, have absolute volumes slightly under, but 
relative volumes much higher, than average values.

The greater blood volume of males than females is due chiefly to the higher red cell volume of the male, the plasma volume of the two sexes differing only slightly (Figure 1). This fact is in keeping with known observations of higher red cell counts, hemoglobin and hematocrit values, basal metabolic rates (DuBois (6)), and vital capacities (Hutchinson (17) and Pratt (18)) of men as compared to women. It is of interest, however, that the total red cell volume of women as compared to that of men is considerably less

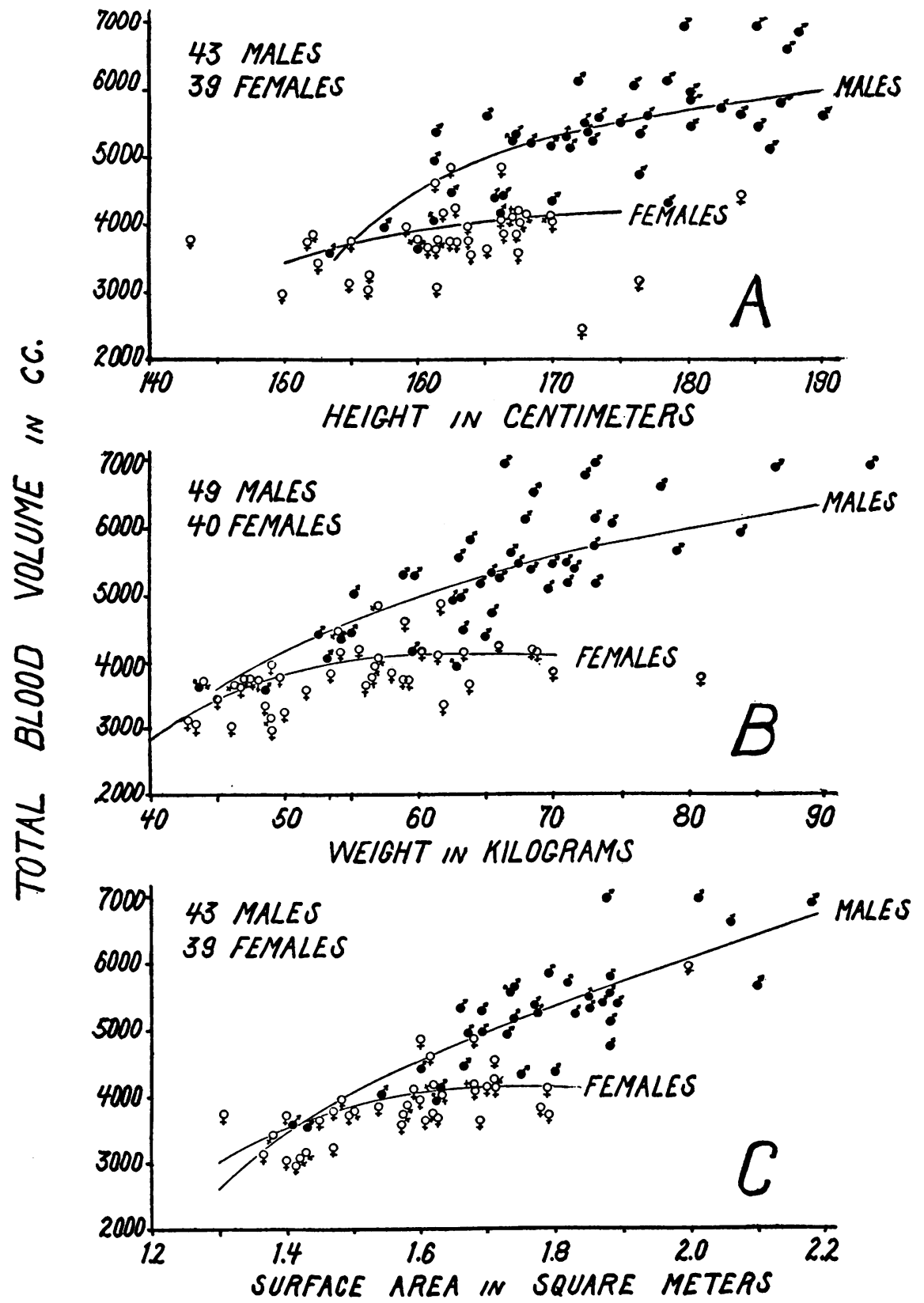

Fig. 4. Relationship of Total Blood Volume to Height, Weight and Surface Area

With increase in size total volume in relation to surface area rises steadily in males, but tends towards a constant value in females. 

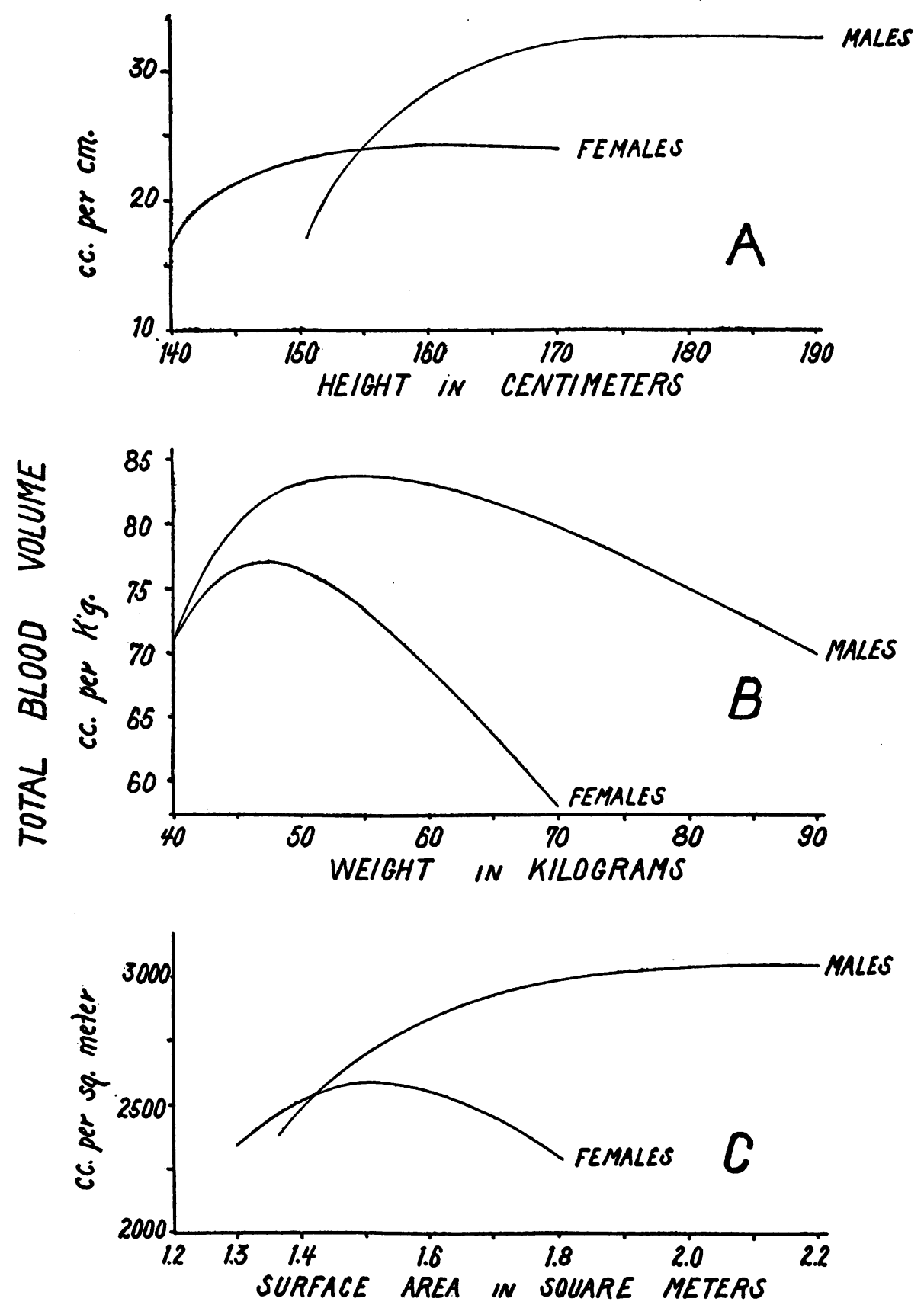

Fig. 5. Relationship of Total Blood Volume in Unit Terms to Differences in Individual Height, Weight and Surface Area

The diminution in unit volume with increasing weight is more pronounced in women than men. With increasing surface area, unit volume rises and tends toward a constant value in men, but decreases in large women. 
than the percentage differences between normal values for red cell counts, hematocrits and hemoglobins would indicate. Thus while average hematocrit values in this series for women are only 10.5 per cent less than for men, the total red cell volume of women is 42.8 per cent less than that of men; the reason being the lower value of both the plasma volume and hematocrit of women. In this connection it should be pointed out that differences in absolute red cell volume of individuals or of changes therein in the same individual cannot be determined on the basis of red cell counts or hematocrits alone. In each case, the plasma volume must be taken into consideration.

That there should be a considerable difference in the blood volume of men and women is not surprising when considered in terms of body weight, and the fact that men as a rule are more muscular and are apt to lead more physically active lives than women. In this connection cer-
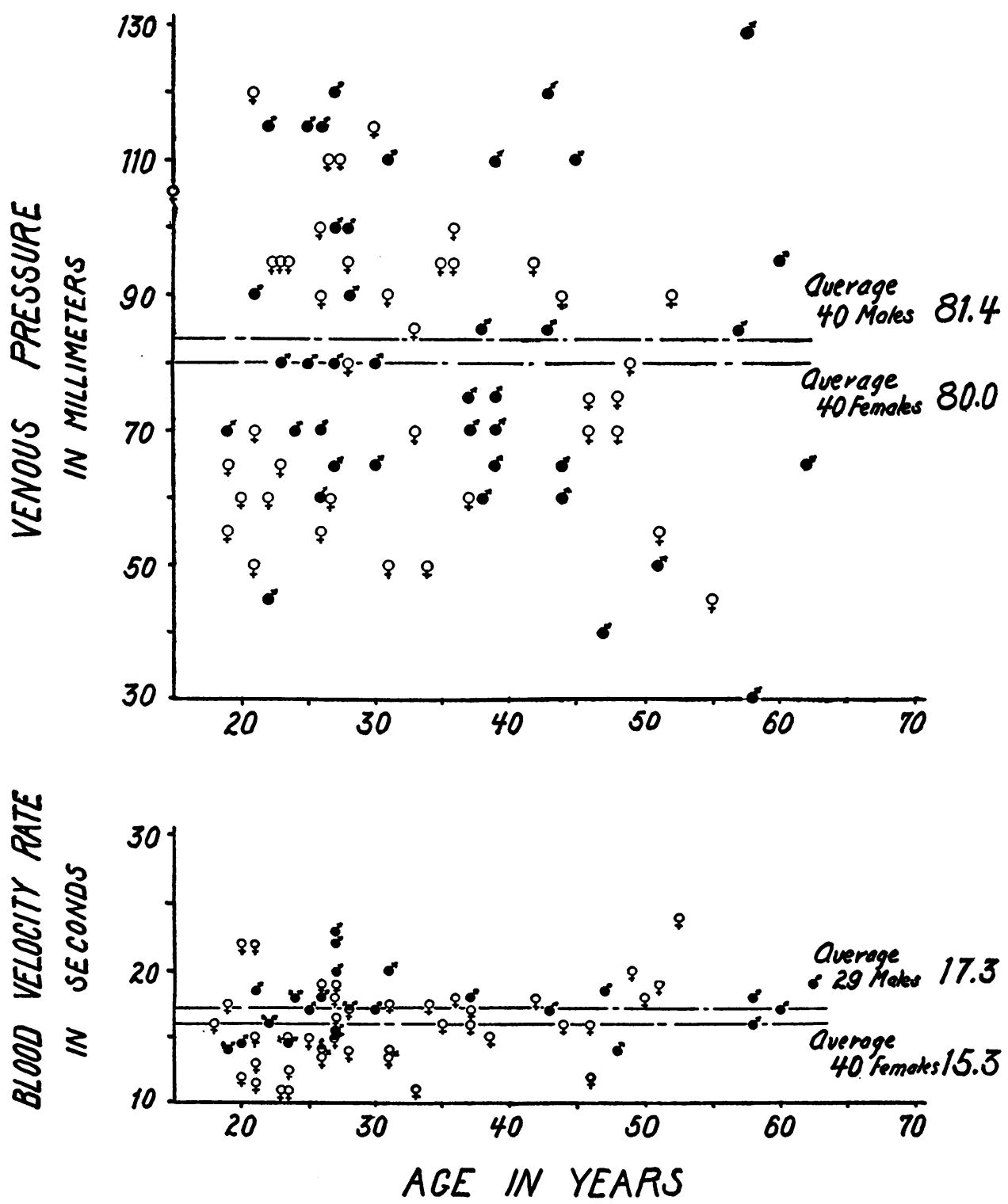

Fig. 6. Venous Pressures and Blood Velocity Rates in 90 Normal Men and Women No relationship of these determinations to age exists in either sex. 
tain cases in this series are of interest as exceptions that prove the rule. Thus Cases 156 and 174 , both athletic women, have high relative volumes well within the male range, while Cases $82 \mathrm{~B}$ and 127 , men of poor muscular development during the life span. Thus Krogh's modification of the Sage standards of basal metabolism (6, p. 157) shows a decrease of 7 per cent in calories per hour between the ages of 25 and 55 . A decrease of about 17 per cent in vital capacity dur-

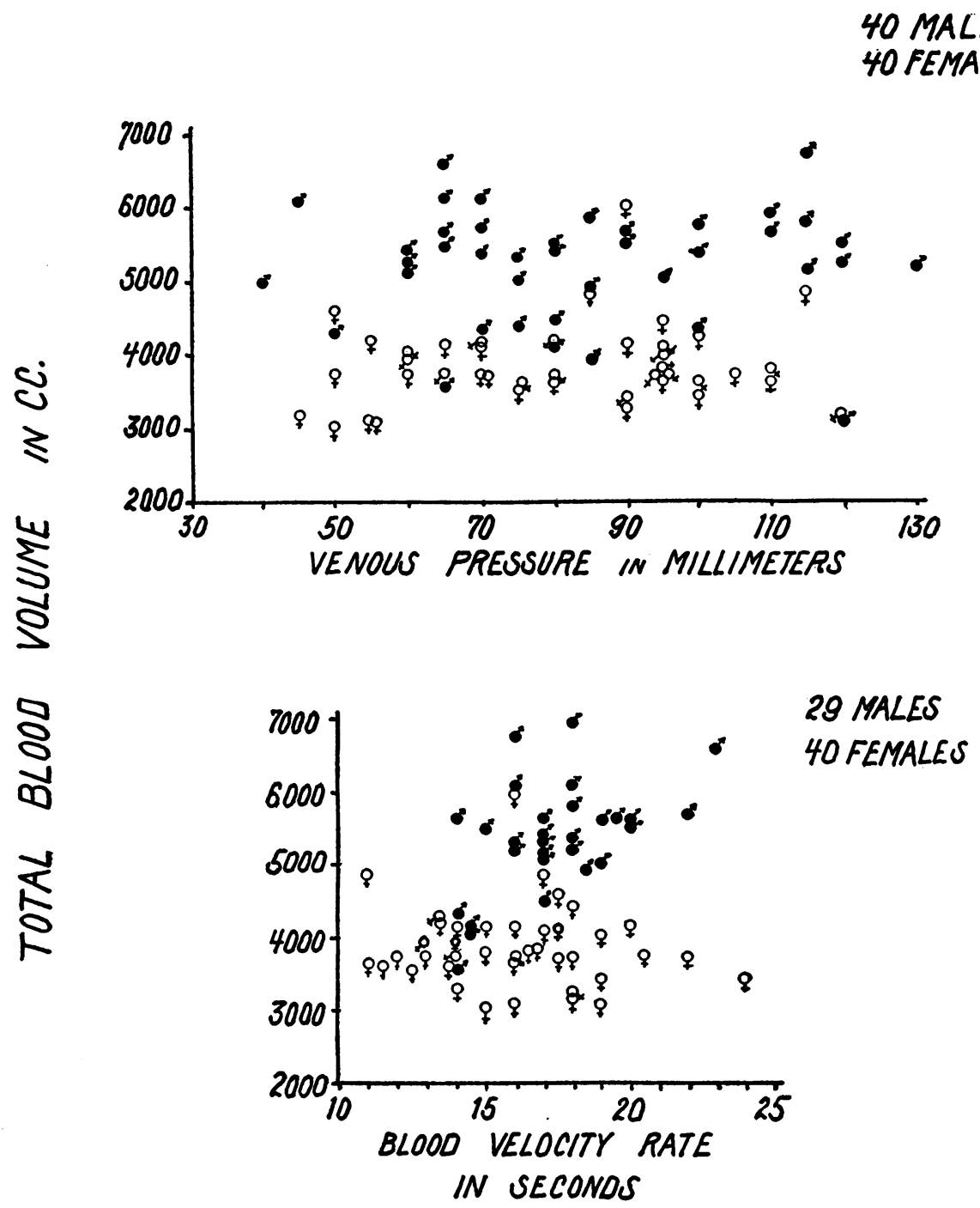

Fig. 7. Relationship of Total Blood Volume to Venous Pressure and Blood Velocity Rate in 90 Normal Men and Women

No relationship to variations in these factors exists in either sex.

and sedentary habits, have relative volumes well below the male average.

The decline in total blood volume with increasing years, amounting to about 14 per cent in males and 10 per cent in females between the ages of 25 and 55 is in keeping with observations on changes in basal metabolism and in vital capacity ing a similar age period is revealed in the studies of Hutchinson (17) and Pratt (18). It seems evident that the total quantity of blood in the normal body bears a definite relation to the oxygen requirement of the body.

The greater percentage decrease in volume in females than in males is consistent with known 
changes in bodily condition taking place with advancing years, particularly in view of the tendency towards obesity occurring in women after the menopause.

The selection of a basis for the determination of normal values for comparative purposes in clinical investigation presents some difficulties. It is apparent that the blood volume of a given for calculation of normal volume on the basis of height or surface area is shown in Figure 8.

\section{CONCLUSIONS}

(1) Plasma and total blood volume, venous pressure and blood velocity rates were determined in 49 normal males and 41 normal females.

(2) No relationship exists in normal persons

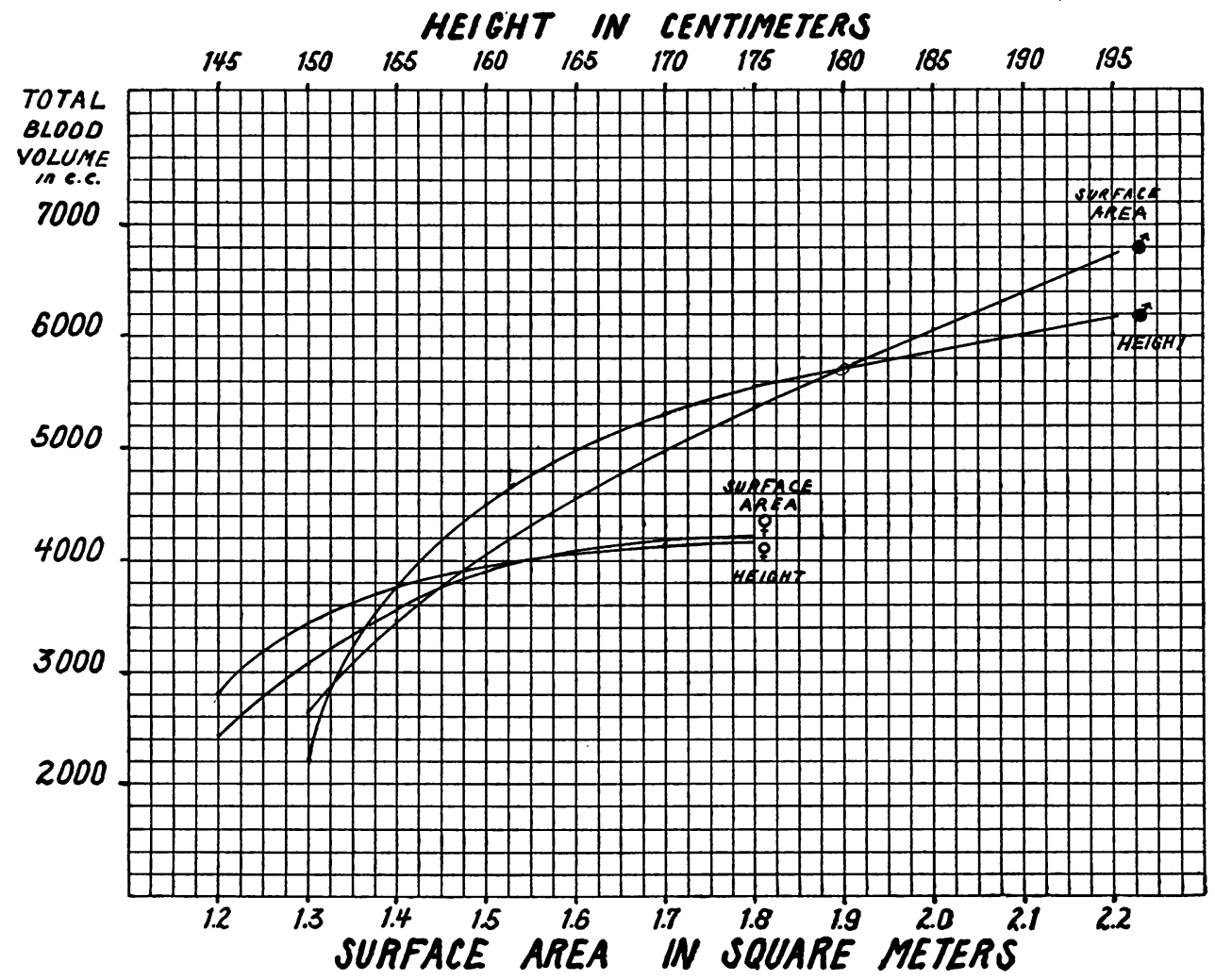

Fig. 8. Chart for Determining Normal Blood Volume for Men and Women on the Basis of Height or Surface Area (as Computed from the Nomogram of Boothby AND SANDIFORD)

individual may be predicted on the basis of height, weight or surface area only within wide limits. The average value found for males and females in this series does not reflect differences due to body size. We feel that in a group of patients, the average of normal values based on surface area in those cases exhibiting no marked disturbance in weight to height relationship, and on height in those cases presenting weight changes due to disease, offers a more useful estimate of normal volume than the average values for the entire group of normals herein reported. A chart between variations in total blood volume, venous pressure and blood velocity rate.

(3) The total blood volume of normal males is greater than that of females, the difference being due to the greater red cell volume of males. The absolute red cell volume of females is less than that of males by a much greater degree than indicated by differences in red cell counts and hematocrit values.

(4) With increasing age there is a decline in the blood volume comparable to decreases in basal metabolic rates and vital capacities. 
(5) In comparison to average values, the absolute total blood volume is high in muscular and obese persons, and low in thin individuals; the volume per unit of body weight is high in muscular and in thin individuals and low in obese persons.

(6) The blood volume of normal individuals varies within wide limits. The relationship to height or surface area offers a useful basis for estimation of normal volume in clinical investigation.

We wish to acknowledge our grateful appreciation to Professor Henry A. Christian for advice and encouragement tendered us in this work; to the many members of the staff of the Peter Bent Brigham Hospital for their coöperation in volunteering as subjects, and to Miss Evelyn Berstein for valuable technical assistance.

\section{BIBLIOGRAPHY}

1. Keith, N. M., Rowntree, L. G., and Geraghty, J. T., A method for the determination of plasma and blood volume. Arch. Int. Med., 1915, 16, 547.

2. Hooper, C. W., Smith, H. P., Belt, A. E., and Whipple, C. H., Blood volume studies. I. Experimental control of a dye blood volume method. Am. J. Physiol., 1920, 51, 205.

3. Seyderhelm, R., and Lampe, W., Die Blutmengenbestimmung und ihre klinische Bedeutung. Unter besonderer Berücksichtigung der Farbstoffmethode. Ergbn. d. inn. Med. u. Kinderh., 1925, 27, 245.

4. Wollheim, E., Die Bestimmung der Zirkulierende Blutmenge. Ztschr. f. klin. Med., 1928, 108, 463.

5. Gibson, J. G., 2nd, and Evans, Wm. A., Jr., Clinical studies of the blood volume. I. Clinical application of a method employing the blue azo dye "Evans Blue" and the spectrophotometer. J. Clin. Invest., 1937, 16, 301.

6. DuBois, E. F., Basal Metabolism in Health and Disease. Lea and Febiger, Philadelphia, 1936, 3d ed.
7. Rowntree, L. G., and Brown, G. E., The Volume of the Blood and Plasma in Health and Disease. W. B. Saunders Co., Philadelphia, 1929.

8. Kaltreider, N. L., Hurtado, A., and Brooks, W. D. W., Study of the blood in chronic respiratory disease with special reference to the volume of the blood. J. Clin. Invest., 1934, 13, 999.

9. Silbert, S., Kornzweig, A. L., and Friedlander, M., Reduction of blood volume in thrombo-angiitis obliterans (Buergers). Arch. Int. Med., 1930, 45, 948.

10. Bock, A. V., The constancy of the volume of the blood plasma. Arch. Int. Med., 1921, 27, 83.

11. Seyderhelm, R., and Lampe, W., Zur Frage der Blutmengenbestimmung. II. Colorimetrische Blutmengenbestimmung mit Trypanblau. Ztschr. f. d. ges. exper. Med., 1922, 30, 410.

12. Wollheim, E., Die zirkulierende Blutmenge und ihre Bedeutung für Kompensation und Dekompensation des Kreislaufs. Ztschr. f. klin. Med., 1931, 116, 269.

13. Kaboth, Uber die normale Blutmenge in der Schwangerschaft. Zentralbl. f. Gynäk., 1923, 47, 498.

14. Sparks, M. I., and Haden, R. L., The blood volume in chronic arthritis. Am. J. M. Sc., 1932, 184, 753.

15. Uhlenbruck, P., and Leyendecker, T., Stufenphotometrische Blut-Plasma-mengenbestimmungen bei Herzkranken, normalpersonen und nach sportlichen anstrengungen. Ztschr. f. Klin. Med., 1931, 118, 164.

16. Gregersen, M. I., Gibson, J. J., and Stead, E. A., Plasma volume determination with dyes; errors in colorimetry; use of the blue dye T-1824. Am. J. Physiol. (Proc.), 1935, 113, 54.

17. Hutchinson, John, On the capacity of the lungs and on the respiratory functions, with a view of establishing a precise and easy method of detecting disease by the spirometer. Med.-Chir. Tr.: Roy. Med. and Chir. Soc., 1846, 29, 137.

18. Pratt, J. H., Long-continued observations on the vital capacity in health and heart disease. Am. J. M. Sc., 1922, 164, 819. 